\title{
ANTESEDEN KOMITMEN ORGANISASIONAL DAN DAMPAKNYA TERHADAP KINERJA TUGAS (JOB PERFORMANCE) GURU
}

\author{
Harif Amali Rivai \\ Fakultas Ekonomi Universitas Andalas Padang \\ e-mail: harifamali@gmail.com
}

\begin{abstract}
The current research examines fit model of relationships among antecedents of organizational commitment (i.e. perceived organizational support, participative leadership style, psychological empowerment) and its impact on job performance of teachers. A theoretical model was estimated using senior high school teachers in Padang. Anonym questionnaires were distributed to maintain confidentiality of the respondents. Two hundred eighty two respondents voluntarily participated and included into statistical analysis. The results of testing model using AMOS 16 found that participative leadership style and perceived organizational support have significant effect on organizational commitment of the teachers. Organizational commitment also demonstrated significant impact on job performance of teachers. Meanwhile, psychological empowerment did not significantly influence on organizational commitment. This study provides insight to help police makers how to improve tearchers' performance. Implication of the research was also discussed in this study.
\end{abstract}

Key words: Perceived organizational support, participative leadership, psychologival empowerment, organizational commitment, job performance.

\begin{abstract}
Abstrak
Penelitian ini bertujuan untuk menguji ketepatan model yang menjelaskan anteseden komitmen organisasional (persepsi atas dukungan organisasional, gaya kepemimpinan partisipatif, pemberdayaan psikologis) dan dampaknya terhadap kinerja tugas guru. Model teoritis penelitian diestimasi dengan menggunakan sampel dari guru-guru yang mengajar pada Sekolah Menengah Atas di kota Padang. Kuesioner tanpa nama (anonym) didistribusikan untuk menjaga kerahasiaan responden. Sebanyak 282 responden dianalisis dalam penelitian ini. Hasil pengujian dengan menggunakan aplikasi AMOS 16.0. menemukan bahwa model teoritikal dapat memenuhi kriteria goodness of fit model. Hasil penelitian mendukung bahwa variable persepsi yang terdiri dari gaya kepemimpinan partisipatif dan dukungan organisasional berpengaruh signifikan terhadap komitmen organisasional para guru. Komitmen organisasional juga memperlihatkan pengaruh yang signifikan terhadap kinerja tugas para guru. Sementara itu, variable pemberdayaan psikologis tidak berpengaruh signifikan terhadap komitmen organisasional. Hasil penelitian ini memberikan kontribusi bagi pengambil kebijakan dalam rangka meningkatkan kinerja tugas guru. Implikasi hasil penelitian juga dibahas lebih lanjut dalam studi ini.
\end{abstract}

Kata kunci: Persepsi atas dukungan organisasional, kepemimpinan partisipatif, pemberdayaan psikologis, komitmen organisasional, kinerja tugas.

\section{PENDAHULUAN}

Studi mengenai kinerja tugas telah menjadi perhatian para akademisi dan praktisi. Kinerja tugas dapat terjemahkan sebagai kinerja dalam konteks kualitas dan kuantitas yang diharapkan oleh guru atau karyawan. Kinerja tugas yang merupakan outcome dari personel dapat dipre- diksi dari berbagai perspektif. Studi sebelumnya telah memperlihatkan hubungan yang positif antara komitmen dan efektifitas kinerja tugas (misalnya Somers and Birnbaum, 1998, Meyer, Paunonen, Gellatly, Goffin and Jackson, 1989, Chughtai and Zafar, 2006). Bogler and Somech (2004) melakukan studi 
dalam konteks institusi pendidikan mendukung bahwa komitment organisasional adalah faktor kunci dalam meningkatkan kinerja para guru dan berdampak pada kualitas pendidikan (Tsui and Cheng, 1999). Komitmen organisasional juga dikonsepsualisasikan oleh Mowday, Porter and Steers (1982) yang mencerminkan (a) sejauhmana individu menerima tujuan dan nilai-nilai yang dibangun institusi, (b) seberapa usaha yang mereka lakukan demi institusi, dan (c) keinginan mereka untuk tetap berkarir di institusi tersebut. Level komitmen yang rendah menyebabkan tingginya tingkat keluar masuk karyawan, sementara itu kepuasan kerja yang tinggi akan menuju kepada peningkatan kinerja (Jackofsky, 1984). Studi oleh Chughtai and Zafar (2006), dengan responden guru-guru di Pakistan menyimpulkan bahwa guru yang berkomitmen tinggi memperlihatkan kinerja yang lebih baik jika dibandingkan dengan guru dengan komitmen yang rendah. Perbedaan tingkat komitmen karyawan dapat terjadi akibat karyawan merasakan perbedaan atas tingkat pemberdayaan yang dirasakannya (Avolio et al., 2004). Memberikan kesempatan pemberdayaan kepada bawahan akan memberi dampak pada peningkatan kontribusi dengan memperlihatkan komitmen mereka (Wayne, Liden and Sparrowe, 2000).

Eisenberger, Huntington, Hutchison, dan Sowa (1986) menjelaskan bahwa konsep komitmen juga meliputi ide dimana karyawan merasakan derajat dimana organisasi tempat mereka bekerja memiliki komitmen kepada mereka, apa yang mereka sebut dengan istilah persepsi atas dukungan organisasional (perceived organizational support - POS). POS mencerminkan sejauh mana karyawan merasa yakin bahwa organisasi tersebut menilai kontribusinya dan peduli dengan kesejahteraannya (Eisenberger et al.,1986). Meskipun hubungan antara POS dan komitmen organisasional telah memperoleh dukungan dari beberapa studi sebelumnya (misal Wayne, Shore, \& Lidenr 1997), namun masih sangat terbatas studi yang menguji anteseden dari komitmen organisasional dalam konteks institusi pendidikan dan dampak kinerja tugas (job performance) dimana para guru sebagai objeknya.

Meskipun telah banyak studi dilakukan dalam rangka menjelaskan anteseden dan konsekuensi dari komitmen organisasional, namun mayoritas studi tersebut dilakukan dalam kon- tek organisasi bisnis dan karyawan rumah sakit (misal perawat). Penelitian ini bertujuan mengusulkan dan menguji model yang mencerminkan hubungan antara psychological empowerment, persepsi terhadap dukungan organisasional, kepemimpinan partisipatif, organizational commitment, dan kinerja tugas (Gambar 1). Penelitian ini juga menginvestigasi peran sertifikasi guru dalam meningkatkan komitmennya untuk membangun kualitas pendidikan. Meskipun dalam telaah literatur dalam studi ini menggunakan istilah "karyawan", namun posisi guru dalam studi ini merupakan bawahan dari pemimpin yang ada di sekolah. Sehingga pada pembahasan literatur lebih lanjut dapat mempertukarkan istilah "guru" dan "karyawan" atau "individu".

\section{KAJIAN PUSTAKA}

\section{Komitmen Organisasional (Organizational Commitment)}

Komitmen adalah keyakinan yang mencerminkan kekuatan dari keterikatan seseorang terhadap organisasi (Grusky, 1966; pada Chew, Girardi and Entrakin, 2005). Komitmen mengacu pada kedekatan psikologis dan emosional seseorang merasa suatu kebanggaan individu terhadap hubungan dan tujuan organisasional, atau kondisi yang dirasakan melibatkan keterikatan emosional, serta evaluasi apakah keadaan saat ini apa yang diharapkan kemungkian akan terjadi di masa depan (Landy and Conte, 2004). Komitmen organisasi dapat mengacu pada reaksi afektif karyawan komitmen untuk seluruh organisasi, khususnya dalam peningkatan kualitas dan derajat keterikatan dan loyalitas terhadap organisasi. Komitmen organisasional dapat diartikan sebagai identifikasi, loyalitas, dan keterlibatan yang dinyatakan oleh karyawan oleh organisasi atau unit dari organisasi (Meyer and Allen, 1991). Menurut William and Hazer (1986), komitmen organisasional merupakan respon afektif pada organisasi secara menyeluruh, yang kemudian menunjukkan suatu respon afektif pada aspek khusus pekerjaan sedangkan kepuasan kerja merupakan respon afektif individu didalam organisasi terhadap evaluasi masa lalu dan masa sekarang, serta penilaian yang bersifat individual bukan kelompok atau organisasi. Sedangkan menurut Mowday, Porter and Steers (1982) komitmen organisasional 
sebagai derajat seberapa jauh karyawan mengidentifikasikan dirinya dengan organisasi dan keterlibatannya dalam organisasi tertentu.

Komitmen terhadap organisasi telah ditemukan berhubungan positif dengan berbagai dampak yang diinginkan, termasuk kepuasan kerja, motivasi dan kinerja (Chen, Tsui and Farh, 2002). Rendahnya level komitmen organisasi di sisi lain, berkorelasi negatif dengan absensi dan tingkat perpindahan karyawan. Definisi awal dari komitmen organisasi diusulkan oleh Mowday, Porter and Steers (1982) mencakup tiga komponen: penerimaan tujuan organisasi dan nilai-nilai, usaha ekstra atas nama organisasi, dan keinginan tetap dengan organisasi. O'Reilly and Chatman (1986) berupaya untuk menjelaskan organisasi komitmen sebagai salah satu fokus atas dasar psikologis karyawan keterikatan pada organisasi. Mereka membedakan tiga unsur komitmen-kepatuhan, identifikasi, dan internalisasidan menyarankan bahwa ketiga unsur dari komitmen mungkin merupakan dimensi terpisah dari komitmen.

\section{Persepsi terhadap Dukungan Organisasional}

\section{(Perceived Organizational Support-POS)}

Persepsi dukungan organisasi mengacu pada persepsi karyawan mengenai sejauh mana organisasi menilai kontribusi, memberi dukungan, dan peduli pada kesejahteraan mereka (Rhoades and Eisenberger, 2002). Jika karyawan menganggap bahwa dukungan organisasi yang diterimanya tinggi, maka karyawan tersebut akan menyatukan keanggotaan sebagai anggota organisasi ke dalam identitas diri mereka dan kemudian mengembangkan hubungan dan persepsi yang lebih positif terhadap organisasi tersebut. Dengan menyatunya keanggotaan dalam organisasi dengan identitas karyawan, maka karyawan tersebut merasa menjadi bagian dari organisasi dan merasa bertanggung jawab untuk berkontribusi dan memberikan kinerja terbaiknya pada organisasi (Rhoades and Eisenberger, 2002). Rhoades dan Eisenberger (2002) mengungkapkan bahwa persepsi terhadap dukungan organisasi juga dianggap sebagai sebuah keyakinan global yang dibentuk oleh tiap karyawan mengenai penilaian mereka terhadap kebijakan dan prosedur organisasi. Keyakinan ini dibentuk berdasarkan pada pengalaman mereka terhadap kebijakan dan prosedur organisasi, penerimaan sumber daya, interaksi dengan agen organisasinya (misalnya supervisor), dan persepsi mereka mengenai kepedulian organisasi terhadap kesejahteraan mereka.

Organisasi merupakan sumber penting bagi kebutuhan sosio-emosional mereka seperti respect (penghargaan), caring (kepedulian), dan tangible benefit seperti gaji dan tunjangan kesehatan. Perasaan dihargai oleh organisasi membantu mempertemukan kebutuhan karyawan terhadap approval (persetujuan), esteem (penghargaan) dan affiliation (keanggotaan) (Eisenberger and Rhoades, 2002). Penilaian positif dari organisasi juga meningkatkan kepercayaan bahwa peningkatan usaha dalam bekerja akan dihargai. Oleh karena itu karyawan akan memberikan perhatian yang lebih atas penghargaan yang mereka terima dari atasan mereka. Persepsi dukungan organisasional merupakan komponen ensensial dari hubungan pertukaran yang berkaitan dengan komitmen organisasional dan keanggotaan dalam tim kerja (Bishop 1998). Teori social exchange yang dikemukakan oleh Blau (1964) mengemukakan bahwa ketika seseorang atau entitas merasakan keberpihakan dari pihak lainnya, mereka yang merasakan keberpihakan seolah-olah berkewajiban untuk membalasnya, meskipun tidak dijelaskan secara rinci kapan dan dalam bentuk apa. Konsepsi tersebut mendasari bahwa karyawan akan memiliki komitmen yang kuat ketika mereka merasakan adanya dukungan atau keberpihakan dari organisasi.

\section{Pemberdayaan Psikologis (Psychological Empowerment)}

Pemberdayaan psikologis merupakan suatu keadaan yang memberikan power dan kendali kepada seseorang, sehingga perasaan mampu untuk melakukan pekerjaan dan memperlancar keadaan yang dapat meningkatkan motivasi instrinsik terhadap tugas, yang dimanifestasikan ke dalam empat kognisi, yaitu: meaning, competence, self-determination dan impact, yang mencerminkan orientasi seseorang terhadap peran pekerjaannya (Spreitzer, Kizilos and Nason 1997). Meaning (keberartian) adalah kesesuaian antara kebutuhan peran pekerjaan seseorang dengan perilaku, keyakinan dan nilai-nilai yang dimiliki oleh seseorang, sehingga orang tersebut merasa bahwa pekerjaan yang dilakukan sekarang, sangat penting 
dan berarti bagi dirinya. Competence (kecakapan) adalah kepercayaan atau keyakinan seseorang bahwa dirinya memiliki keterampilan dan kemampuan yang diperlukan untuk melakukan tugas atau pekerjaan dengan baik. Self-determination (determinasi diri) adalah keyakinan seseorang bahwa orang tersebut mempunyai kebebasan atau otonomi dan kendali tentang bagaimana mengerjakan pekerjaannya sendiri. Impact (dampak) adalah persepsi bahwa seseorang secara signifikan dapat mempengaruhi strategi, administrasi dan hasil operasi kerja perusahaan.

Literatur manajemen merumuskan pemberdayaan berdasarkan teori pertukaran sosial (social exchange theory) (Homans, 1974 dalam Conger and Kunango, 1988), sehingga literatur ini menafsirkan kekuasaan sebagai sebuah fungsi ketergantungan dan kemandirian dari para pelaku (actor). Kedua, pemberdayaan sebagai konstruk motivasional. Dalam literatur psikologi, kekuasaan dan kendali digunakan sebagai kondisi kepercayaan (belief state), yang bersifat motivasional atau yang mengandung pengharapan dan bersifat informal dalam diri tiap-tiap individu. Dalam artian motivasional, kekuasaan adalah kebutuhan instrinsik dari dalam individu untuk memiliki kebebasan membuat keputusan (self-determination) (Deci, Connel and Ryan, 1989), atau kebutuhan instrinsik untuk merasa yakin pada efektifitas diri (self-efficacy) (Bandura, 1989). Pemberdayaan dalam konstruk relasional adalah "to empower" (memberdayakan), sedangkan dalam konstruk motivasional, pemberdayaan berarti "to enable" (memungkinkan, membuat bisa, memampukan).

\section{Kepemimpinan Partisipatif (Participative Leadership)}

Kepemimpinan partisipatif menyangkut penggunaan berbagai macam prosedur keputusan yang memberikan orang lain suatu pengaruh tertentu terhadap keputusan-keputusan pemimpin. Istilah-istilah lain yang biasanya digunakan untuk menunjuk kepada aspek-aspek kepemimpinan partisipatif mencakup konsultasi, pengambilan keputusan bersama, membagi kekuasaan, desentralisasi serta manajemen yang demokratis (Yulk, 1998). Kepemimpinan partisipatif menyangkut usaha-usaha seorang pemimpin untuk mendorong atau memudahkan partisipasi orang lain dalam pengambilan keputusan yang jika tidak dibuat sendiri oleh pimpinan. Mengikutsertakan orang lain dalam pengambilan keputusan adalah suatu bagian yang perlu dari proses politisi untuk memperoleh keputusan dan implementasi dalam organisasi atau perusahaan (Yulk, 1998)

Kepemimpinan partisipatif melibatkan konsultasi dengan bawahan dan mengevaluasi opini dan anjuran sebelum mengambil keputusan (Mullins, 2005). Kepemimpinan partisipatif berhubungan dengan consensus, konsultasi, delegasi, dan keterlibatan (Bass, 1981). Studi yang dilakukan Bass (1981) menunjukkan bahwa karyawan yang merasakan atasnya mengadopsi kepemimpinan konsutatif atau partisipatif akan lebih memiliki komitmen yang tinggi dan merasa lebih terpuaskan dengan pekerjaannya, akibatnya kinerja juga akan meningkat (Yousef, 2000).. Karena sifat konsultatif dari kepemimpinan partisipatif, hal ini akan membawa potensi untuk meningkatkan penyebaran nilai-nilai manajerial dan organisasional pada karyawan. Karyawan yang bekerja pada organisasi dengan pemimpin partisipatif cenderung memperlihatkan keterlibatan yang lebih tinggi dalam pekerjaan, demikian juga komitmen dan loyalitas yang lebih baik dibandingkan dengan pemimpin yang direktif (Bass, 1981).

\section{Keterkaitan antara Persepsi Dukungan Organisasional (POS) dan Komitmen Organisasional}

Studi tentang hubungan POS dan komitmen telah dilakukan dalam berbagai setting organisasi seperti maufaktur dan kesehatan, namun tidak banyak dibahas dalam kontek institusi pendidikan. Hubungan antara POS dan komitmen dapat dijelaskan dengan teori social exchange yang dikemukakan oleh Blau (1964) dan social identity theory yang dikemukakan oleh Tyler (1999). Menurut teori tersebut, individu yang merasa mendapat pengakuan dalam organisasi ketika pimpinan menilai kontribusinya atas fungsi organisasi (lihat Fuller et al., 2003). Pengakuan atas status dan pekerjaan dalam organisasi membantu memenuhi kebutuhan socio-emotional karyawan, yaitu kebutuhan penghargaan, persetujuan, dan afiliasi (Shore and Shore, 1995). Kebutuhan socioemotional yang merasa terpenuhi berkontribusi dalam membangun identitas sosial, yang nantinya akan meningkatkan rasa kebanggaan dan 
memiliki dalam organisasi (Meyer and Allen 1991). Studi yang dilakukan Meyer and Allen (1991) mendukung bahwa terdapat pengaruh positif POS terhadap affective commitment. Hubungan yang didasarkan atas pertukaran sumberdaya yang dinilai individu yang berinteraksi satu sama lainnya. Dalam konteks hubungan antara POS dan affective commitment, socio-emotional dan aspek-aspek simbolik dari pertukaran menjadi pertimbangan individu (Shore et al., 2006). Persepsi dan pengalam dari dukungan organisasional dapat menjadi faktor kritikal dalam membangun komitmen. Studi yang dilakukan Cohen and Abedallah (2013) mengungkapkan bahwa terdapat korelasi antara persepsi atas dukungan organisasional dengan komitmen pada guru. Studi yang serupa dilakukan oleh Aube, Rousseau and Morin (2007) mengungkapkan bahwa POS merupakan variable yang dapat meningkatkan rasa memiliki dan kebanggaan terhadap organisasi. Dengan demikian untuk memperlihatkan penghargaan terhadap pimpinan, karyawan mengembangkan sikap positif terhadap organisasi dengan meningkatkan komitmen, maka dihipotesiskan:

H1: Persepsi terhadap dukungan organisasional berpengaruh signifikan terhadap komitmen organisasional.

\section{Keterkaitan Psychological Empowerment and Organizational Commitment}

Empowerment atau pemberdayaan didefinisikan sebagai peningkatan motivasi tugas intrinsic yang dimanifestasikan dalam empat kognisi yang mencerminkan orientasi individu terhadap peran pekerjaannya: compentence, impact, meaning dan self-determination. Competence mengacu kepada perasaan self-efficacy atau penguasaan personal yang mana seseorang mampu mencapai kesuksesan dalam melaksanakan tugas (Bandura, 1986). Impact mengacu kepada derajat dimana pekerjaan individu membuat perbedaan dalam mencapai tujuan tugas dan sejauhmana individu yakin mempengaruhi outcome organisasi. Meaning mengacu kepada bobot individu yang menempatkan tugas yang diberikan berdasarkan standar individu, dan self-determination atau pilihan mengacu kepada perasaan autonomi dalam membuat keputusan tentang pekerjaan. Wayne, Liden and Sparrowe (2000) beragumen bahwa memberikan kesempatan kepada bawahan untuk tantangan, tanggungjawab, dan keputusan, juga self-determination akan memberi dampak pada peningkatan kontribusi dengan memperlihatkan komitmen mereka. Bawahan yang diberdayakan akan melihat dirinya lebih kapabel dan akan mampu mempengaruhi organisasi dan pekerjaannya dengan cara-cara yang lebih berarti. Jika demikian juga akan membawa pengaruh kepada individu untuk memperlihatkan usaha yang ekstra, bertindak independen, dan memiliki komitmen yang lebih tinggi (Spreitzer, 1995). Oleh karena itu, jika bawahan diberdayakan maka akan memperlihatkan balas jasa dalam bentuk komitmen kepada atasan atau organisasi. Persepsi terhadap pemberdayaan psikologis diyakini mampu meningkatkan komitmen organisasional (Malik et al., 2013). Studi yang dilakukan oleh Avolio, Zhu, Koh, dan Bhatia (2004) dengan menggunakan responden perawat mengungkapkan bahwa perbedaan dalam level komitmen bawahan dapat terjadi sebagai akibat perbedaan bagaimana bawahan merasa diberdayakan oleh karyawan senior atau supervisor. Dengan demikian dapat dihipotesiskan:

H2: Semakin meningkat persepsi terhadap level pemberdayaan psikologis, maka akan semakin meningkat komitmen organisasional

\section{Kepemimpinan Partisipatif dan Komitmen Organisasional}

Perkembangan literatur dalam manajemen menunjukkan bahwa perilaku kepemimpinan dapat mempengaruhi kinerja organisasi. Perilaku partisipatif dari pemimpin dapat memberikan dampak terhadap komitmen bawahan. Kepemimpinan partisipatif bertujuan untuk meningkatkan partisipasi pengikut dengan memberikan mereka lebih kewenangan, perhatian, pengaruh, dukungan, informasi, dan sumberdaya lainnya; dan untuk berbagi isu dari pemecahan masalah dengan para pengikut dengan berkonsultasi sebelum membuat keputusan (Bass, 1990). Studi yang dilakukan oleh Koberg, Boss, Senjem and Goodman (1999) menemukan bahwa gaya kepemimpinan yang partisipatif mampu meningkatkan komitmen karyawan ketika diberi pemberdayaan pada karyawan. Studi yang dilakukan oleh Huang, Shi, Zhang and Cheung (2006) dalam konteks karyawan BUMN di China mengungkapkan bahwa kepemimpinan partisipatif tidak ber- 
hubungan signifikan dengan psychological empowerment, namun berpengaruh positif dan signifikan terhadap komitmen organisasional. Mengacu kepada exchange-based model, kepemimpinan partisipatif membawa pesan bahwa seorang atasan memiliki keyakinan atas bawahannya, memberikan perhatian, dan menghargai bawahannya. Perilaku kepemimpinan yang demikian memungkinkan untuk menumbuhkan tingkat kepercayaan yang tinggi dari atasan. Kondisi tersebut memungkina bawahan untuk memberikan imbal balik kepada atasan dengan memperlihatkan sikap dan perilaku yang lebih baik. Pada studi yang berbeda, Dolatabadi and Safa (2010) menguji dua model kepemimpinan, yaitu direktif dan partisipatif, dalam hubungannya terhadap komitmen pada kualitas pelayanan di industri perbankan Iran. Hasil studinya mendukung bahwa gaya kepemimpinan yang partisipatif secara langsung mempengaruhi pembentukan komitmen karyawan terhadap kualitas pelayanan. Perilaku kepemimpinan partisipasipatif memberikan peluang kepada bawahan untuk berpartisipasi dalam pengambilan kebijakan. Studi yang dilakukan Saad (2012) memberikan dukungan empiris bahwa partsipasi guru dalam dalam penyusunan rencana pembelajaran memperlihatkan peningkatan komitmen yang signifikan. Dengan demikian dapat dikemukakan hipotesis berikut:

H3: Gaya kepemimpinan partisipatif akan berpengaruh signifikan terhadap komitmen organisasional.

\section{Komitmen Organisasional dan Kinerja Tugas}

Beberapa hasil studi mendukung hubungan antara komitmen organisasional dan kinerja tugas dalam organisasi. Malaviha (2005) menyimpulkan bahwa komitmen organisasionl saling terkait satu sama lainnya. Studi yang dilakukan Brett, Cron and Slocum (1995) menyelidiki hubungan antara komitmen dan kinerja tugas dengan menggunakan ketergantungan ekonomi pada pekerjaan sebagai variable moderasi dan melaporkan bahwa hubungan antara komitmen dan kinerja adalah lebih kuat pada mereka yang tuntutan finansial rendah daripada yang lebih tinggi. Dalam konteks profesi sebagai guru, pemerintah telah berusaha meningkatkan kesejahteraan guru dengan memberikan tunjangan sertifikasi. Program peningkatan kesejahteraan melalui peningkatan tunjangan tersebut diharapkan mampu untuk meningkatkan komitmen guru dalam menjalankan tugas. Proses pemberian tunjangan sertifikasi dilakukan dengan pola seleksi dan tidak secara serentak. Oleh karena itu guru penerima sertifikasi belum terdistribusi dengan merata, dengan kata lain dalam suatu sekolah kemungkinan terdapat kelompok guru yang telah dan yang belum tersertifikasi. Dengan demikian dapat hipotesiskan:

H4: Persepsi Dukungan Organisasi berpengaruh positif dan signifikan terhadap kinerja tugas.

H5: Pemberdayaan Psikologis berpengaruh positif dan signifikan terhadap kinerja tugas.

H6: Komitmen Organisasional berpengaruh positif dan signifikan terhadap kinerja tugas.

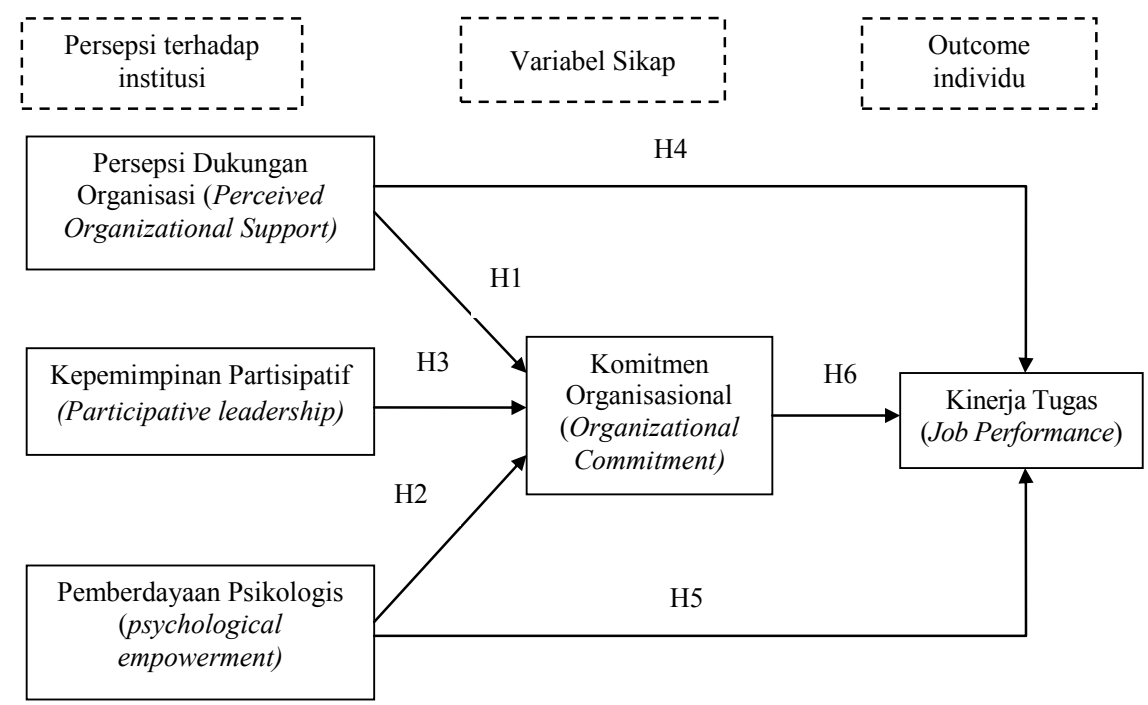

Gambar 1: Model teoritis penelitian 


\section{METODE PENELITIAN}

Penelitian yang dimaksudkan untuk pengujian model dengan menggunakan structural equation modeling (SEM). Hair et al., (2010) menyarankan agar memperoleh model yang fit dengan sampel diharapkan kisaran sampel antara 200-400 responden. Sampel penelitian ini adalah guru SMA di kota Padang. Pengambilan sampel dilakukan dengan metode nonprobability sampling, yaitu dengan pendekatan convenience sampling. Metode sampling tersebut mengacu kepada pengumpulan informasi dari anggota populasi yang secara mudah dijumpai (Sekaran and Bougie 2010), sehingga tingkat respon yang diharapkan semakin tinggi. Sebanyak 6 SMA setuju untuk berpartisipasi dalam penelitian, yang terdiri dari tiga milik pemerintah dan tiga bukan milik pemerintah. Sejumlah 300 kuesioner didistribusikan dan kuesioner yang kembali dengan tingkat respon sebesar 94\% (282 kuesioner).

Instrument penelitian diadopsi dari penelitian yang dilakukan sebelumnya dengan menggunakan skala likert 5 poin. Dukungan organisasional diadopsi dari penelitian yang dilakukan Eisenberg et al., (1986) dengan jumlah 12 item. Pemberdayaan psikologis diukur dengan instrument yang dikembangkan oleh Spreitzer (1995) yang terdiri dari 6 item skala likert 5 poin. Kepemimpinan partisipatif berhubungan dengan consensus, konsultasi, delegasi, dan keterlibatan. Skala pengukuran dikembangkan dari Bass (1981) yang terdiri dari 5 item dengan menggunakan skala likert 5 poin $(1=$ sangat tidak setuju $-5=$ sangat setuju $)$. Komitmen organisasional diadopsi dari Meyer dan Allen (1997) yang terdiri dari 6 item pertanyaan dengan menggunakan skala likert 5 poin $(1=$ sangat tidak setuju $-5=$ sangat setuju). Sedangkan kinerja tugas didefinisikan diadopsi dari instrument yang dikembangkan oleh Malaviha (2005) yang terdiri dari 14 item pertanyaan dengan menggunakan skala likert 5 poin.

Untuk menguji hipotesis dan menghasilkan suatu model yang fit, analisis yang digunakan pada penelitian ini adalah structural equation modelling (SEM) dengan dibantu program aplikasi AMOS. Dengan menggunakan structural equation modeling yang dihasilkan AMOS akan diperoleh indikator-indikator model yang fit. Kriteria yang dipertimbangkan untuk mengidentifikasi model persamaan struktural yang baik dengan menggunakan analysis of moment structure (AMOS) (Arbuckle, 1997), yaitu: 1) Degree of freedom (DF) harus positif. 2) Chi square non signifikan di atas yang disyaratkan $(\mathrm{p}=0,05)$ dan juga di atas batas konservatif yang diterima $(\mathrm{p}=0,10)$ (Hair et al., 1998). 3) Incremental fit di atas 0,9 yaitu untuk GFI (Goodness of Fit Index), Adjusted GFI (AGFI), Tucker-Lewis Index (TLI) dan Normed Fit Index (NFI). 4) Nilai Root Mean Square Residual (RMR) dan Root Mean Square Error of Approximation (RMSEA) yang rendah.

\section{HASIL DAN PEMBAHASAN}

Mayoritas responden berjenis kelamin perempuan yaitu sebesar $75,2 \%$. Responden yang memiliki usia dibawah 30 tahun terdiri dari 43 guru atau $15,2 \%$, dengan usia rata-rata 44,3 tahun. Responden dengan status guru tetap adalah sebanyak 187 guru atau 66,3\%, kemudian diikuti oleh guru tidak tetap (honorer) sebanyak 85 guru $(30,1 \%)$. Sedangkan guru berstatus selain guru tetap atau honorer sebanyak 10 guru $(3,5 \%)$ dan rata-rata masa kerja mereka sebagai guru adalah 6,4 tahun.

Berdasarkan pada tingkat pengeluaran per bulan. Pada urutan pertama, responden yang terbanyak adalah responden yang memiliki kategori pengeluaran antara $\mathrm{Rp}$ 3.000 .000 - Rp 4.000.000 yakni sebanyak 82 guru atau $29,1 \%$. Diikuti oleh kategori pengeluaran antara $\mathrm{Rp} 2.000 .000$ - Rp 3.000 .000 yakni sebanyak 64 guru $(22,7 \%)$. Kemudian diikuti oleh kategori pengeluaran dibawah Rp 2.000 .000 sebanyak 56 guru (19,9\%). Sedangkan kategori pengeluaran antara $\mathrm{Rp} 4.000 .000$ - Rp 5.000.000 sebanyak 46 guru (16,3\%) dan kategori pengeluaran diatas $\mathrm{Rp} \quad 5.000 .000$ sebanyak 34 guru atau $12,1 \%$. Jika dilihat dari katagori guru tersebut telah disertifikasi atau tidak. Mayoritas guru yang diteliti telah memiliki sertifikasi atau serifikat pendidik, yakni sebanyak 186 guru atau 66\%. Sedangkan guru yang belum memiliki serifikat pendidik sebanyak 96 guru atau 34\%.

Uji Validitas dilakukan dengan menggunakan analisis faktor dalam rangka menilai single underlying construct, dimana nilai factor loading item yang valid dalam konstruk yaitu diatas 0,5 (Nunnally, 1987). Uji reliabilitas dilakukan dengan pengukuran cronbach alpha, 
dimana suatu konstruk yang reliable dengan kisaran nilai alpha antara 0,6 dan 1(Sekaran and Bouge 2010). Kisaran hasil uji reliabilitas konstruk dengan ditemukan antara 0,8 dan 0,9, maka dapat disimpulkan semua konstruk tersebut reliabel

Uji normalitas bertujuan untuk mengetahui bagaimana pendistribusian data dalam variabel yang akan digunakan dalam penelitian.
Pengujian normalitas dilakukan dengan mengamati nilai critical ratio skewness data yang digunakan, apabila nilai CR (critical ratio) pada skewness data berada pada rentang antara $\pm 2,58$ pada tingkat signifikansi 0,05 maka dapat dikatakan bahwa data tersebut terdistribusi normal. Selanjutnya hasil pengujian terhadap normalitas bahwa semua data terdistribusi dengan normal

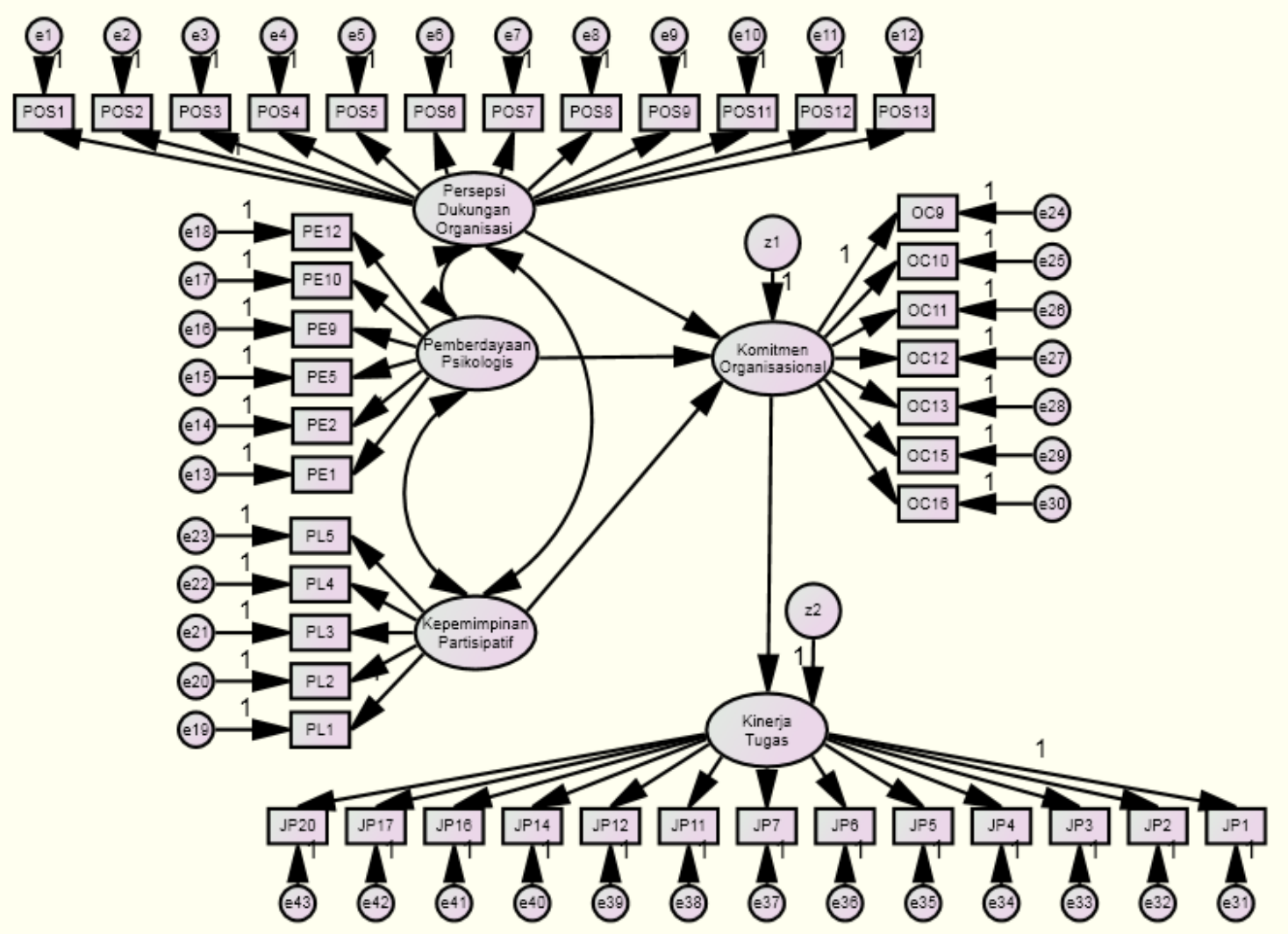

Sumber : Hasil Pengolahan AMOS

Gambar 2: Structural Equation Modeling

Tabel 1: Goodness of Fit Index

\begin{tabular}{lccc}
\hline Goodness of fit index & Cut of Value & $\begin{array}{c}\text { Hasil } \\
\text { Analisis }\end{array}$ & Evaluasi Model \\
\hline Degree of Freedom & Positif & 736 & Baik \\
Probability & $\geq 0,05$ & 0,000 & Cukup Baik \\
RMSEA & $\leq 0,08$ & 0,037 & Baik \\
GFI & $\geq 0,90$ & 0,838 & Cukup Baik \\
AGFI & $\geq 0,90$ & 0,792 & Cukup Baik \\
CMIN/DF & $\leq 2,0$ & 1,273 & Baik \\
TLI & $\geq 0,95$ & 0,958 & Baik \\
CFI & $\geq 0,95$ & 0,966 & Baik \\
\hline
\end{tabular}

Sumber : Hasil Pengolahan AMOS 
Tabel 2: Hasil Pengujian Hubungan antar Variabel

\begin{tabular}{llrrrc}
\hline & & Estimate & S.E & \multicolumn{1}{c}{ C.R } & Keterangan \\
\hline Komitmen_Organisasional & $\leftarrow$ Persepsi_Dukungan_Organisasi &, 174 &, 138 & 1,966 & Signifikan \\
Komitmen_Organisasional & $\leftarrow$ Pemberdayaan_Psikologis &, 081 &, 149 &, 543 & Tidak signifikan \\
Komitmen_Organisasional & $\leftarrow$ Kepemimpinan_Partisipatif &, 106 &, 023 & 2,107 & Signifikan \\
Kinerja_Tugas & $\leftarrow$ Komitmen_Organisasional &, 124 &, 037 & 2,013 & Signifikan \\
Kinerja_Tugas & $\leftarrow$ Persepsi_Dukungan_Organisasi &, 138 &, 070 & 1,992 & Signifikan \\
Kinerja_Tugas & $\leftarrow$ Pemberdayaan_Psikologis &, 377 &, 092 & 7,981 & Signifikan \\
\hline
\end{tabular}

Ket : $* * *=$ nilai $P$ leboh kecil dari 0,001

Sumber: Hasil Pengolahan AMOS

Hasil analisis pengolahan data pada SEM memperhatikan semua konstruk yang digunakan untuk membentuk sebuah model penelitian berdasarkan kriteria model yang fit, maka proses analisis full model SEM tersebut telah memenuhi kriteria goodness of fit yang telah ditetapkan. Ukuran goodness of fit yang menunjukkan kondisi yang fit hal ini disebabkan oleh nilai degree of freedom (DF) yang positif yakni sebesar 736, dengan nilai probability yang kurang baik yakni 0,000 atau dibawah 0,05 , nilai ini menunjukkan adanya perbedaan antara matriks kovarian sample dengan matriks kovarian populasi yang diestimasi. Ukuran goodness of fit lain juga menunjukkan pada kondisi yang baik yaitu TLI $(0,958) ; \quad$ CFI $\quad(0,966) ; \quad$ CMIN/DF $(1,273)$; RMSEA $(0,037)$ telah memenuhi kriteria goodness of fit. Sedangkan nilai GFI $(0,838)$ dan AGFI $(0,792)$ masih berada dalam batas toleransi sehingga dapat diterima.

Pengujian selanjutnya adalah uji signifikansi kausalitas melalui uji koefisien regresi (regression weight). Pengujian dilakukan melihat nilai CR, loading factor (estimate) dan probabilitasnya. Nilai $\mathrm{CR}$ yang disyaratkan adalah diatas $\pm 1,96$, yang berarti signifikan pada $\mathrm{p}$ value $\leq 0,05$. Lihat tabel 2 .

Dari pengolahan AMOS diatas dapat dilihat bahwa semua hubungan antar variabel yang dihipotesiskan menunjukkan hasil yang signifikan, kecuali hipotesis yang menyatakan hubungan antara pemberdayaan psikologis dengan komitmen organisasional dimana nilai CR $<1,96$.

\section{HASIL DAN PEMBAHASAN}

Hipotesis 1 pada penelitian ini adalah persepsi terhadap dukungan organisasi atau sekolah (perceive organizational support-POS) ditemu- kan berpengaruh signifikan terhadap komitmen organisasional (organizational commitment) guru terhadap sekolah. Sehingga semakin meningkat dukungan organisasional, maka akan semakin tinggi komitmen organisasional guru di sekolah. Hubungan antara persepsi dukungan organisasional (POS) dan komitmen dapat dijelaskan dengan teori social exchange yang dikemukakan oleh Blau (1964) dan social identity theory yang dikemukakan oleh Tyler (1999). Studi yang dilakukan Meyer and Allen (1991) mendukung bahwa terdapat pengaruh positif POS terhadap komitmen individu. Hubungan yang didasarkan atas pertukaran sumberdaya yang dinilai individu yang berinteraksi satu sama lainnya. Studi yang serupa dilakukan oleh Aube, Rousseau and Morin (2007) mengungkapkan bahwa POS merupakan variable yang dapat meningkatkan rasa memiliki dan kebanggaan terhadap organisasi. Dengan demikian POS dapat dikatakan sebagai variabel yang mendahuli berkembangnya komitmen organisasional para guru. Persepsi terhadap dukungan organisasi juga dapat meningkatkan keyakinan tiap karyawan mengenai penilaian mereka terhadap kebijakan dan prosedur organisasi. Mereka menilai berdasarkan pengalaman mereka terhadap kebijakan dan prosedur organisasi, penerimaan sumber daya, interaksi dengan agen organisasinya (misalnya supervisor), dan persepsi mereka mengenai kepedulian organisasi terhadap kesejahteraan mereka (Rhoades dan Eisenberger, 2002). Dapat disimpulkan bahwa individu yang memiliki pandangan positif terhadap dukungan organisasional akan berupaya untuk meningkatkan komitmen terhadap organisasi tempat mereka bekerja.

Oleh karena itu, dalam meningkatkan kompetensi guru dan persepsi yang baik terhadap institusi (perceive organizational sup- 
port-POS), pihak sekolah harus mampu menghargai kontribusi guru dalam mengajar dengan memperhatikan masalah kesejahteraan, sekolah perlu untuk memberikan apresiasi atas kerja keras guru dalam mengajar, pihak sekolah sebaiknya secara rutin menerima saran dari para guru dalam perbaikan kualitas pembelajaran, pihak sekolah seharusnya melibatkan majelis guru dalam proses pengambilan keputusan strategis sekolah, pihak sekolah perlu untuk membantu para guru dalam menyelesaikan setiap permasalahan yang dihadapi terkait proses pembelajaran, serta pihak sekolah perlu untuk terus melakukan inovasi dan pembaharuan dalam lingkungan sekolah, fasilitas-fasilitas penunjang proses belajar-mengajar, maupun inovasi terhadap kurikulum dan rancangan pembelajaran. Sehingga persepsi guru tersebut terhadap sekolah atau institusi (perceive organizational support-POS) dapat memberikan dampak positif terhadap komitmen guru dalam mengajar.

Hipotesis 2 pada penelitian ini adalah persepsi terhadap level pemberdayaan psikologis (psychological empowerment) berpengaruh secara signifikan terhadap komitmen organisasional (organizational commitment) guru terhadap sekolah. Sehingga semakin tinggi tingkat pemberdayaan psikologis, maka semakin tinggi komitmen organisasi guru di sekolah. Berdasarkan hasil pengujian dapat dapat disimpulkan bahwa hipotesis 2 pada penelitian ini tidak didukung. Hal ini membuktikan bahwa tidak terdapat pengaruh signifikan pemberdayaan psikologis (psychological empowerment), terhadap komitmen organisasi (organizational commitment) guru di sekolah.

Hasil studi ini memperlihatkan ketidakkonsistenan dengan temuan studi sebelumnya yang berkembang dalam literature. Wayne, Liden and Sparrowe (2000) beragumen bahwa memberikan kesempatan kepada bawahan untuk mendapat tantangan, tanggungjawab, dan kewenangan keputusan, serta self-determination akan memberi dampak pada peningkatan kontribusi terhadap komitmen mereka. Bawahan yang diberdayakan akan melihat dirinya lebih kapabel dan akan mampu mempengaruhi organisasi dan pekerjaannya dengan caracara yang lebih berarti. Jika demikian juga akan membawa pengaruh kepada individu untuk memperlihatkan usaha yang ekstra, bertindak independen, dan memiliki komitmen yang lebih tinggi (Spreitzer, 1995). Studi sebelumnya mengungkapkan bahwa bawahan yang diberdayakan maka akan memperlihatkan balas jasa dalam bentuk komitmen kepada atasan atau organisasi. Perbedaan dalam level komitmen bawahan dapat terjadi sebagai akibat perbedaan bagaimana bawahan merasa diberdayakan oleh karyawan senior atau supervisor (Avolio, Zhu, Koh and Bhatia, 2004).

Temuan studi ini memperlihatkan bahwa tidak terdapat perngaruh signifikan pemberdayaan psikologis (psychological empowerment) guru terhadap komitmen organisasi guru. Peran sekolah dalam melakukan pemberdayaan psikologis kepada guru tidak memiliki pengaruh yang dominan karena guru lebih membutuhkan pemberdayaan yang bersifat fisik (hard skill), seperti kebijakan pemberdayaan dalam peningkatan kualitas keilmuan atau akademik guru, pembuatan karya ilmiah, serta kebijakan mengenai sarana dan prasarana fisik dalam menunjang proses pembelajaran. Seperti yang telah dijelaskan sebelumnya, hal ini dikarenakan organisasi pendidikan memiliki karakteristik yang berbeda dengan organisasi berorientasi laba atau perusahaan, seperti yang telah diteliti pada studi-studi terdahulu. Komitmen organisasional (organizational commitment-OC) guru terhadap sekolah kemungkinan lebih dipengaruhi oleh variabelvariabel selain dari pemberdayaan psikologis (psychological empowerment). Komitmen karyawan diduga dipengaruhi oleh variabelvariabel lainnya seperti faktor kompensasi, gaji, tunjangan, benefit, pelatihan dan pengembangan, bantuan dalam melanjutkan pendidikan ke strata yang lebih tinggi, manajemen karir yang jelas bagi guru, kualitas kehidupan kerja, penilian kinerja dan kontrol terhadap kualitas belajar mengajar yang diberikan oleh guru secara rutin oleh pihak sekolah.

Peningkatkan kompetensi guru melalui pemberdayaan psikologis (psychological empowerment), pihak sekolah harus mampu meningkatkan kepercayaan diri guru dalam mengajar, memberikan kebebasan kepada guru dalam mengembangkan proses dan mekanisme dalam belajar, memberikan keyakinan yang kuat kepada para guru, serta memberikan wewenang kepada guru atas apa yang terjadi di sekolah. Sehingga pemberdayaan psikologis (psychological empowerment) yang dilakukan sekolah terhadap guru dapat memberikan 
dampak positif terhadap komitmen guru dalam mengajar.

Hasil pengujian hipotesis 3 menunjukkan bahwa gaya kepemimpinan partisipatif (participative leadership) berpengaruh signifikan terhadap komitmen organisasional (organizational commitment) guru di sekolah tersebut. Semakin diterapkannya gaya kepemimpinan partisipatif maka akan semakin meningkat komitmen organisasional guru-guru. Hal ini konsisten dengan studi sebelumnya tentang hubungan antara gaya kepemimpinan partisipatif dan komitmen organisasi. Studi yang dilakukan oleh Koberg, Boss, Senjem, \& Goodman (1999) menemukan bahwa gaya kepemimpinan yang partisipatif mampu meningkatkan komitmen karyawan ketika diberi pemberdayaan pada karyawan. Studi yang dilakukan oleh Huang, Shi, Zhang and Cheung (2006) dalam konteks karyawan BUMN di China mengungkapkan bahwa kepemimpinan partisipatif tidak berhubungan signifikan dengan $p s y$ chological empowerment, namun berpengaruh positif dan signifikan terhadap komitmen organisasional. Mengacu kepada exchangebased model, kepemimpinan partisipatif membawa pesan bahwa seorang atasan memiliki keyakinan atas bawahannya, memberikan perhatian, dan menghargai bawahannya. Kondisi tersebut memungkina bawahan untuk memberikan imbal balik kepada atasan dengan memperlihatkan sikap dan perilaku yang lebih baik. Pada studi yang berbeda, Dolatabadi and Safa (2010) menguji dua model kepemimpinan, yaitu direktif dan partisipatif, dalam hubungannya terhadap komitmen pada kualitas pelayanan di industri perbankan Iran. Hasil studinya mendukung bahwa gaya kepemimpinan yang partisipatif secara langsung mempengaruhi pembentukan komitmen karyawan terhadap kualitas pelayanan.

Pada penelitian ini, gaya kepemimpinan partisipatif (participative leadership) pimpinan sekolah berpengaruh signifikan terhadap komitmen organisasi guru. Gaya kepemimpinan yang diterapkan oleh kepala sekolah memiliki dampak terhadap komitmen guru maupun terhadap kinerja guru dalam mengajar. Hal ini dikarenakan para pimpinan sekolah sudah mulai melibatkan konsultasi dengan bawahan dan mengevaluasi opini dan anjuran sebelum mengambil keputusan (Mullins, 2005). Bass (1981) megungkapkan bahwa kepemimpinan partisipatif berhubungan dengan consensus, konsultasi, delegasi, dan keterlibatan. Guru-guru yang mempersepsikan kepemimpinan bersifat konsultatif atau partisipatif akan lebih memiliki komitmen yang tinggi dan merasa lebih terpuaskan dengan pekerjaannya, akibatnya kinerja juga akan meningkat (Yousef, 2000).. Gaya kepemimpinan ini berpotensi untuk meningkatkan penyebaran nilainilai manajerial dan organisasional kepada para guru-guru.

Oleh karena itu, dalam meningkatkan kompetensi guru melalui penerapan gaya kepemimpinan partisipatif (participative leadership), pihak sekolah harus mampu berkonsultasi kepada para guru ketika menghadapi suatu masalah, menerima ide dan gagasan baru dari para guru, berkonsultasi kepada guru dalam mengambil kebijakan strategis, meminta usul dari para guru terkait bagaimana menyelesaikan suatu tugas atau masalah, serta rutin untuk menanyakan kepada para guru tentang program apa yang seharusnya dibuat. Sehingga penerapan gaya kepemimpinan partisipatif (participative leadership) yang dilakukan sekolah terhadap guru dapat memberikan dampak positif terhadap komitmen guru dalam mengajar.

Hipotesis 4 pada penelitian ini adalah persepsi terhadap dukungan organisasi atau sekolah (perceive organizational support-POS) berpengaruh terhadap kinerja tugas (job performance) guru di sekolah. Sehingga semakin tinggi tingkat persepsi terhadap dukungan organisasi, maka semakin tinggi kinerja tugas guru di sekolah. Hubungan antara POS dan kinerja dapat dijelaskan dengan teori social exchange yang dikemukakan oleh Blau (1964) dan social identity theory yang dikemukakan oleh Tyler (1999). Menurut teori tersebut, individu yang merasa mendapat pengakuan dalam organisasi ketika pimpinan menilai kontribusinya atas fungsi organisasi (lihat Fuller et al., 2003). Studi yang serupa dilakukan oleh Aube, Rousseau and Morin (2007) mengungkapkan bahwa POS merupakan variable yang dapat meningkatkan rasa memiliki dan kebanggaan terhadap organisasi.

Pada penelitian ini, persepsi dukungan organisasional (perceive organizational support-POS) guru terhadap sekolahnya berpengaruh signifikan terhadap kinerja tugas (job performance) guru di sekolah. Persepsi yang baik 
terhadap institusi akan meningkatkan kinerja guru karena adanya keyakinan terhadap institusi yang telah memberikan perhatian dan peran yang luas dan independen kepada para guru dalam mengembangkan proses belajar mengajar di dalam kelas. Selain itu sekolah telah berhasil membangun hubungan yang baik dengan para guru sehingga guru memiliki persepsi yang baik terhadap sekolah. Kinerja yang baik akan berdampak pada kualitas pembelajaran yang diberikan oleh guru tersebut kepada para murid. Kualitas yang baik akan mampu menghasilkan murid yang berkualitas sehingga dapat meningkatkan prestasi akademik murid maupun prestasi akademik sekolah secara umum.

Oleh karena itu, dalam meningkatkan kinerja guru dan persepsi yang baik terhadap institusi (perceive organizational supportPOS), pihak sekolah harus mampu menghargai kontribusi guru dalam mengajar dengan memperhatikan masalah kesejahteraan, sekolah perlu untuk memberikan apresiasi atas kerja keras guru dalam mengajar, pihak sekolah sebaiknya secara rutin menerima saran dari para guru dalam perbaikan kualitas pembelajaran, pihak sekolah seharusnya melibatkan majelis guru dalam proses pengambilan keputusan strategis sekolah, pihak sekolah perlu untuk membantu para guru dalam menyelesaikan setiap permasalahan yang dihadapi terkait proses pembelajaran, serta pihak sekolah perlu untuk terus melakukan inovasi dan pembaharuan dalam lingkungan sekolah, fasilitas-fasilitas penunjang proses belajar-mengajar, maupun inovasi terhadap kurikulum dan rancangan pembelajaran. Sehingga persepsi guru tersebut terhadap sekolah atau institusi (perceive organizational support-POS) dapat memberikan dampak positif terhadap kinerja guru dalam mengajar.

Hipotesis 5 pada penelitian ini adalah persepsi terhadap level pemberdayaan psikologis (psychological empowerment) berpengaruh secara signifikan terhadap kinerja tugas (job performance) guru di sekolah. Sehingga semakin tinggi tingkat pemberdayaan psikologis, maka semakin tinggi kinerja tugas guru di sekolah. Hal ini sejalan dengan studi sebelumnya tentang hubungan pemberdayaan psikologis dan kinerja tugas. Jika bawahan diberdayakan maka akan memperlihatkan balas jasa dalam bentuk komitmen kepada atasan atau organisasi. Studi yang dilakukan oleh Avolio, Zhu, Koh and Bhatia (2004) dengan menggunakan responden perawat mengungkapkan bahwa perbedaan dalam level komitmen bawahan dapat terjadi sebagai akibat perbedaan bagaimana bawahan merasa diberdayakan oleh level karyawan senior atau level supervisor.

Pada penelitian ini, pemberdayaan psikologis (psychological empowerment) guru terhadap sekolahnya berpengaruh signifikan terhadap kinerja tugas (job performance) guru. Kinerja dalam mengajar sangat dipengaruhi oleh motivasi, dorongan, semangat, dan penghargaan yang diberikan oleh sekolah terhadap para guru. Guru yang telah diberdayakan akan memberikan dampak terhadap performance guru di dalam kelas. Selain itu, peran sekolah dalam melakukan pemberdayaan psikologis perlu diperluas meliputi pemberdayaan yang bersifat fisik (hard skill), seperti kebijakan pemberdayaan dalam peningkatan kualitas keilmuan atau akademik guru, pembuatan karya ilmiah, serta kebijakan mengenai sarana dan prasarana fisik dalam menunjang proses pembelajaran. Selain itu, dalam meningkatkan kinerja, pihak sekolah perlu memperhatikan faktor, gaji, tunjangan, benefit, pelatihan dan pengembangan, bantuan dalam melanjutkan pendidikan, manajemen karir bagi guru, kualitas kehidupan kerja, penilian kinerja dan kontrol terhadap kualitas belajar mengajar.

Oleh karena itu, dalam meningkatkan kinerja guru (job performance) melalui pemberdayaan psikologis (psychological empowerment), pihak sekolah harus mampu meningkatkan kepercayaan diri guru dalam mengajar, memberikan kebebasan kepada guru dalam mengembangkan proses dan mekanisme dalam belajar, memberikan keyakinan yang kuat kepada para guru, serta memberikan wewenang kepada guru atas apa yang terjadi di sekolah. Sehingga pemberdayaan psikologis (psychological empowerment) yang dilakukan sekolah terhadap guru dapat memberikan dampak positif terhadap kinerja guru (job performance) dalam mengajar.

Hipotesis 6 pada penelitian ini adalah persepsi terhadap komitmen organisasional (psychological empowerment) berpengaruh secara signifikan terhadap kinerja tugas (job performance) guru di sekolah. Sehingga semakin tinggi komitmen organisasional, maka semakin baik kinerja tugas guru di sekolah. Hal 
ini sejalan dengan studi sebelumnya tentang hubungan komitmen dan kinerja tugas. Beberapa hasil studi mendukung hubungan antara komitmen organisasional dan kinerja tugas dalam organisasi. Malaviha (2005) menyimpulkan bahwa komitmen organisasionl saling terkait satu sama lainnya. Studi yang dilakukan Brett, Cron and Slocum (1995) menyelidiki hubungan antara komitmen dan kinerja tugas dengan menggunakan ketergantungan ekonomi pada pekerjaan sebagai variabel moderasi dan melaporkan bahwa hubungan antara komitmen dan kinerja adalah lebih kuat pada mereka yang tuntutan finansial rendah daripada yang lebih tinggi.

Pada penelitian ini, komitmen organisasional guru terhadap sekolahnya berpengaruh signifikan terhadap kinerja tugas (job performance) guru. Kinerja dalam mengajar sangat dipengaruhi oleh tingkat kebahagiaan guru di sekolah, kebanggaan guru tersebut atas keberadaannya di sekolah, hubungan emosional yang baik dengan sekolah, rasa memiliki yang cukup tinggi terhadap sekolah, loyalitas guru dalam mengajar di sekolah tersebut, serta sulitnya bagi guru untuk mempertimbangkan pindah ke sekolah yang lain. Hal-hal tersebut yang menjadi indikator-indikator yang akan meningkatkan kinerja guru. Guru yang memiliki komitmen organisasi yang tinggi, maka akan berusaha untuk menyelesaikan tugas mengajarnya dengan baik, memenuhi tanggung jawabnya sesuai dengan peraturan akademik, memenuhi persyaratan kinerja formal dalam mengajar, mematuhi aspek-aspek pekerjaan yang ditugaskan kepadanya, bersikap kooperatif sesama guru di dalam sekolah, mau membantu guru lain yang memiliki beban mengajar yang berlebihan, mau mematuhi kebijakan dari pimpinan sekolah, mampu mengenyampingkan kepentingan pribadi demi tugas mengajar, mampu disiplin dalam menjalankan tugas, tidak mengambil waktu istirahat yang berlebihan, tidak sering mengeluh, serta guru tersebut berusaha melindungi barang-barang atau aset milik sekolah.

Berdasarkan penelitian ini, meskipun guru tersebut telah mendapatkan insentif dan tunjangan terkait dengan sertifikasi guru yang telah didapat, hal itu tidak menjadi penentu dalam meningkatkan komitmen organisasi atau komitmen terhadap sekolah. Sebaliknya, bagi guru yang belum mendapatkan sertifikasi, maka tidak akan mempengaruhi tingkat komitmen mereka dalam melaksanakan proses belajar mengajar di sekolah.

\section{KESIMPULAN, IMPLIKASI, DAN KETERBATASAN}

Keberhasilan mengembangkan kualitas pendidikan dalam sebuah institusi dapat dipengaruhi oleh faktor institusional dan faktor individual. Secara individual lebih banyak ditentukan oleh faktor karakter individu pendidik yang berkembang selama menjalani proses belajar mengajar di institusi pendidikan tersebut. Fokus kajian pada penelitian ini dibatasi dengan menganalisis hubungan dan pengaruh beberapa variabel yang terdiri dari persepsi dukungan organisasi (perceive organizational support), pemberdayaan psikologis (psychological empowerment), kepemimpinan partisipatif (participative leadership), komitmen organisasi (organizational commitment) dan kinerja tugas (job performance). Serta menganalisis tingkat perbedaan antara guru-guru yang telah dan belum memiliki sertifikat pendidik.

Berdasarkan hasil pengujian hipotesa pertama, ditemukan bahwa persepsi dukungan organisasi (perceived organizational supportPOS) berpengaruh signifikan terhadap komitmen organisasional guru (organizational commitment). Pengaruh variabel kepemimpinan partisipatif (participative leadership) signifikan terhadap komitmen organisasional guru (organizational commitment). Demikian juga pengaruh variabel persepsi dukungan organisasi (perceive organizational support-POS) dan , pemberdayaan psikologis guru (psychological empowerment) terhadap komitmen organisasional guru (organizational commitment) juga ditemukan memperlihatkan pengaruh yang signifikan. Namun, hasil penelitian tidak menemukan pengaruh signifikan antara pemberdayaan psikologis dan komitmen organisasional para guru.

Hasil penelitian ini memberikan implikasi dalam upaya peningkatan kinerja tugas para guru terutama dari perspektif sikap dan persepsi guru. Faktor-faktor penentu yang berdampak langsung terhadap kinerja tugas adalah Komitmen organisasional, POS, dan pemberdayaan psikologis, serta kepemimpinan partisipatif. Diantara faktor tersebut, pember- 
dayaan psikologis memberikan kontribusi yang paling berarti terhadap kinerja tugas. Oleh karena itu dalam rangka meningkatkan kinerja guru, pimpinan di sekolah perlu memperluas pendelegasian dalam rangka perberdayaan para guru. Sementara itu faktor penting bagi guru yang memberikan dampak langsung terhadap peningkatan komitmen adalah dukungan organisasional dan diikuti oleh gaya kepemimpinan yang partisipatif. Dalam meningkatkan kinerja guru (job performance) melalui peningkatan komitmen organisasional guru (organizational commitment), pihak sekolah harus mampu meningkatkan meningkatkan kebanggaan guru tersebut atas keberadaannya di sekolah, memperkuat hubungan emosional yang baik dengan sekolah.

Penelitian ini juga tidak lepas dari keterbasan-keterbatasn yang mungkin dapat mempengaruhi kepada hasil penelitian. Pertama, penelitian ini menggunakan sampel dalam institusi yang homogen yang guru-guru SMA, sehingga perlu hati-hati dalam generalisasi hasil studi. Kedua, penelitian ini hanya membatasi pada beberapa variabel seperti yang telah dibahas di atas, namun demikian kemungkinan terdapat variabel lain yang juga berkontribusi dan dapat diteliti. Ketiga, pengambilan sampel dilakukan dengan teknik non probability random sehingga kemungkinan akan mempengaruhi hasilnya. Sehingga penelitian yang akan datang diharapkan dapat memperluas sampel, menambah variabel predictor, dan menggunakan teknik probabilitas sampel random, dengan demikian akan memberikan hasil yang lebih akurat.

\section{DAFTAR PUSTAKA}

Aube, C., V. Rousseau and EM. Morin. 2007. Perceived organizational support and organizational commitment: The moderating effect of locus of control and work otonomi. Journal of Managerial Psychology .22 (5). 479-495

Avolio, BJ., W. Zhu, W. Koh and P. Bhatia. 2004. Transformational leadership: mediating role of psychological empowerment and moderating role of structural distance. Journal of Organizational Behavior. 25. 951-968.
Bass, BM. 1990. Handbook of leadership: A survey of theory and research. New York, USA: Free Press.

Bass, BM. 1981. Personal selling and transactional/transformational leadership. Journal of Personal Selling and Sales Management. 17(3). 19-28.

Bandura, A. 1989. Human agency in social cognitive theory. American Psychological Review. 84 (1). 1175-1184.

Bishop, JW., KD. Scott and LS. Casino. 1997. The differential effect of team commitment and organizational commitment on job performance and intention to quit. Paper presented at Annual Meeting of Academy of Management, Boston.

Blau, PM. 1964. Exchange and power in social life. New York. John Willey \& Sons, Inc.

Bogler, R. and Somech, A. 2004. Influence of Teacher Empowerment on Teachers' Organizational Commitment, Professional Commitment and Organizational Citizenship Behavior in Schools. Teaching and Teacher Education. 20(3). 277-289.

Uma Sekaran and R. Bougie. 2010. Research Methods for Business: A Skill Building Approach. UK: John Wiley \& Sons.

Brett, JF., WL. Cron and JW. Slocum Jr. 1995. Economic Dependency on Work: A Moderator of the Relationship Between Organizational Commitment and Performance. Academy of Management Journal. 38(1). 261-271.

Chen, ZX., AS. Tsui and JL. Farh. 2002. Loyalty to Supervisor vs. Organizational Commitment: Relationships to Employee Performance in China. Journal of Occupational and Organizational Psychology. 75. 339-356.

Chew, J., A. Girardi and L. Entrakin. 2005. Retaining Core Staff: The Impact of Human Resources Practices on Organisational Commitment. Journal of Comparative International Management. 8 (2). $23-42$. 
Chughtai, AA. and S. Zafar. 2006. Antecedents and consequences of Organizational Commitment Among Pakistani University Teachers. Applied H.R.M Research.11 (1). 39-64.

Cohen, A. and A. Abedalla. 2013. Work and Non-work Determinants of Organizational Commitment: A Study of Arab Teachers in Israel. International Journal of Management. 30 (4).

Conger, JA. and RN. Kanungo. 1988. The empowerment process: integrating theory and practice. Academy of Management Review. 13. 417-482.

Deci, EL., JP. Connell and R.M. Ryan. 1989. Self determination in a work organization, Journal of Applied Psychology. 74. 580-590.

Dolatabadi, HR and M. Safa. 2010. The Effect of Directive and Participative Leadership Style on Employees' Commitment to Service Quality. International Bulletin of Business Administration. (9). 31-42.

Eisenberger, R., R. Huntington, S. Hucthison and D. Sowa. 1986. Perceived organizational support. Journal of Applied Psychology. 71 (3). 500-507.

Hasibuan, M. 2007. Manajemen Sumber Daya Manusia. Cetakan Kesembilan. Jakarta: Bumi Aksara.

Hair, J F., B. Black, B. Babin, RE. Anderson, and RL. Tatham. 2010. Multivariate Data Analysis: A Global Perspective, New Jersey, USA: Pearson Education Inc .

Huang, X., K. Shi, Z. Zhang and YL. Cheung. 2006. The impact of participative leadership behavior on psychological empowerment and organizational commitment in Chinese state-owned enterprises: the moderating role of organizational tenure. Asia Pacific Journal Management. 23. 345-367.

Jackofsky, EF. 1984. Turnover and Job Performance: An Integrated Process Model. Academy of Management Review. 9 (1). 74-83.
Koberg, CS., RW., Boss, JC. Senjem and EA. Goodman. 1999. Antecendents and outcomes of empowerment: Empirical evidence from health care industry. Group and Organization Management. 24. 71-91.

Landy, FJ. and JM. Conte. 2004. Work in the 21 st Century; An Introduction to Industrial and Organizational Psychology. New York: McGraw-Hill Companies Inc. Zainal Ariffin Ahmad \& Co.

Luthans, F .1995. Organizational Behavior. Seventh Edition, New York: McGraw Hill Book Co, Inc.

Malik, F., S. Chugtai, Z. Iqbal and Z. Ramzan. 2013. Does Psychological Empowerment Bring About Employee Commitment? Evidence from Telecommunication Sector of Pakistan. Journal of Business Studies Quarterly. 5 (1).

Malaviha. 2005. Impact of organisational climate on employee performance. Paper presented on National Seminar on HRD challenges in software industries, Voorhees College, Vellore. September 16-17.

Meyer, JP. and NJ. Allen. 1997. Commitment in the Workplace: Theory, Research and Application. Newbury Park. CA: Sage.

Meyer, JP., and NJ. Allen. 1991. A Threecomponent Conceptualization of Organizational Commitment",Human Resource Management Review. 1(1). 61-89.

Mowday, R., L. Porter and R. Steers. 1982. Employee-organization Linkages: The Psychology of Commitment, Absenteeism, and Turnover. New York: Academic Press.

Meyer, JP., V. Paunonen, IR. Gellatly, RD., Goffin and DN. Jackson. 1989. Organizational commitment and job performance: It's the nature of the commitment that counts. Journal of Applied Psychology. 74(1). 152-156. 
Mullins, LJ. 2005. Management and organizational behavior. 7th ed. Pearson International.

Nunnally. 1978. Psychometric Theory $\left(2^{\text {nd }}\right.$ ed). New York: McGraw-Hill.

O'reilly, C. and J. Chatman. 1986. Organizational Commitment and Psychological Attachment: The Effects of Compliance, Identification, and Internalization on Prosocial Behaviour", Journal of Applied Psychology. 71. 492-499.

Saad, N. 2012. The Effects of Teachers' Participation in Decision Making on Commitment. The International Journal of Interdisciplinary Social Sciences. 6 (9).

Shore, LM., LE.Tetrick, P. Lynch and K. Barksdale. 2006. Social and economic exchange: construct development and validation. Journal of Applied Social Psychology. 36 (4). 837-867.

Short, PM and JS. Rinehart. 1993. Teacher Empowerment and School Climate (Where Today is Tomorrow in Health Care). Education Article. June.

Somers, JM. and D. Birnbaum. 1998. WorkRelated Commitment and Job Performance: It's also the Nature of the Performance That Counts. Journal of Organizational Behavior. 19 (6). 621-634.

Shore, LM. and TH. Shore. 1995. Perceived organizational support and organizational justice. In Cropanzano, RS. \& KM. Kacmar (Eds.). Organizational politics, justice, and support: Managing the social climate of the workplace. 149-164. Westport, CT: QuoRum.

Spreitzer, GM., Kizilos, MA., \& Nason, SW. (1997). A dimensional analysis of the relationship between psychological empowerment and effectiveness, satisfaction and strain. Journal of Management. vol 23 (5): 679-704.
Tsui, KT. and YC. Cheng. 1999. School organizational health and teacher commitment: A contingency study with multi-level analysis. Educational Research and Evaluation. 5. 249-268.

Tyler, TR. 1999. Why people cooperate with organizations: an identity-based perspective, in Sutton, R. I and Staw. B.M. (eds). Research in Organizational Behavior. Greenwich, CT: JAI Press. 201-47.

Wayne, SJ., LM. Shore and RC. Lidern. 1997. Perceived organizational support and leader-member exchange: A social exchange perspective. Academy of Management Journal. 49 (1). 82-111.

Wayne, S., R. Liden and R. Sparrowe. 2000. An examination of the mediating role of psychological empowerment on the relationship between the job, interpersonal relationships, work outcomes. Journal of Applied Psychology. 85. 407-416.

Williams LJ. and JT. Hazer. 1986. Antecedent and Consequences of Satisfaction and Commitment in Turnover Models: A Reanalysis Using Latent Variable Structural Equation Model. Journal of Applied Psycology. 71(2). 219-231.

Weick, K. 1985. Sources of Order in Underorganized Systems: Themes in Recent Organizational Theory. in: Y S Lincoln (Ed.), Organizational Theory and Inquiry. The Paradigm Revolution. Beverly Hills, CA: Sage.

Yousef, DA. 2000. Organizational commitment: a mediator of the relationships of leadership behavior with job satisfaction and performance in a non-western country. Journal of Managerial Psychology.15(1).

Yulk, G. 2005. Kepemimpinan Dalam Organisasi. Edisi kelima. Jakarta: PT Indeks. 